\title{
LIÊN QUAN GIŨ'A NÒNG ĐỌ PEPSIN TRONG NƯỚC BỌT VỚI KÉT QUẢ NỘI SOI VÀ MÔ BỆNH HỌC Ở BỆNH NHÂN CÓ TRIẸU CHỨNG TRÀO NGƯỢC DẠ DÀY THỰC QUẢN
}

\author{
Đào Việt Hằng ${ }^{1,2,3, 凶}$, Trần Thị Thu Trang ${ }^{1,4}$ và Lưu Thị Minh Huế ${ }^{1}$ \\ ${ }^{1}$ Viện Nghiên cứu và Đào tạo Tiêu hóa, gan mật \\ ${ }^{2}$ Trường Đại học Y Hà Nội \\ ${ }^{3}$ Bệnh viện Đại học Y Hà Nội \\ ${ }^{4}$ Trường Đại học Y Dược, Đại học Quốc gia Hà Nội
}

Nghiên cứu mô tả trên 30 bệnh nhân có triệu chứng trào ngược dạ dày thực quản được thực hiện các kĩ thuật định tính và định lượng pepsin trong nước bọt (Peptest), nội soi đường tiêu hoá trên và sinh thiết niêm mạc thực quản trong quá trình nội soi. Tỉ lệ bệnh nhân có Peptest dương tính ở ít nhất một mẫu và dương tính ở cả hai mẫu nước bọt lần lượt là $100 \%$ và $83,3 \%$. Tỉ lệ bệnh nhân có viêm niêm mạc thực quản trên nội soi và mô bệnh học lần lượt là $70 \%$ và 36,7\%. Không có sụ̣ khác biệt về tỷ lệ Peptest dương tính giữa nhóm có và không có tổn thương viêm niêm mạc thực quản trên kết quả nội soi và mô bệnh học $(p>0,05)$. Nồng độ pepsin ở mẫu sau ăn tối và trước ăn sáng có trung vị lần lượt là 124,1 và 104,5 ng/m/ và đều không có sự khác biệt có ý nghĩa thống kê giữa nhóm có và không có tổn thương viêm niêm mạc thực quản trên nội soi và mô bệnh học $(p>0,05)$.

Từ khóa: Peptest, nội soi đường tiêu hóa trên, mô bệnh học, trào ngược dạ dày thực quản.

\section{I. ĐẠT VẤN ĐÊ}

Trào ngược dạ dày thực quản (GERD) được định nghĩa là tình trạng khi có dịch dạ dày trào ngược lên thực quản gây nên các triệu chứng khó chịu kèm hoặc không kèm biến chứng. ${ }^{1}$ Biểu hiện của GERD khá đa dạng, bên cạnh hai triệu chứng điển hình là trào ngược và cảm giác nóng rát sau xương ức, các bệnh nhân có thể có các biểu hiện không điển hình tại các cơ quan, bộ phận khác như tai - mũi - họng, đường hô hấp dưới hoặc đau ngực không do tim. ${ }^{2}$ Trong những trường hợp này, chẩn đoán GERD dựa vào lâm sàng gặp nhiều khó khăn. Theo đồng thuận Lyon, nội soi đường tiêu hóa trên với tổn thương viêm thực quản trào ngược nặng (Los Angeles

Tác giả liên hệ: Đào Việt Hằng

Viện Nghiên cứu và Đào tạo Tiêu hóa, gan mật

Email: hangdao.fsh@gmail.com

Ngày nhận: 22/02/2021

Ngày được chấp nhận: 08/03/2021 từ $\mathrm{C}$ trở lên hoặc có biến chứng hẹp, loét) hoặc thời gian niêm mạc thực quản tiếp xúc acid (AET) $>6 \%$ trên đo $\mathrm{pH}$ trở kháng 24 giờ được coi là tiêu chuẩn vàng để chẩn đoán. ${ }^{3}$ Tuy nhiên, đo $\mathrm{pH}$ trở kháng 24 giờ là một kĩ thuật xâm lấn và chi phí tương đối cao, cần được thực hiện bởi bác sỹ được đào tạo chuyên sâu, do đó không phải cơ sở y tế nào cũng có điều kiện thực hiện. Nội soi đường tiêu hóa trên là một kĩ thuật thăm dò phổ biến, thường áp dụng trên lâm sàng để đánh giá các rối loạn và tổn thương tại thực quản. Tuy nhiên hình ảnh nội soi có thể không phát hiện tổn thương ở 2/3 người có triệu chứng GERD điển hình. ${ }^{4}$ Sinh thiết niêm mạc thực quản đánh giá tình trạng viêm ít được sử dụng trên lâm sàng do cần nhà giải phẫu bệnh có chuyên môn và kinh nghiệm, sử dụng các thang điểm đánh giá chuẩn hóa, tuy nhiên có giá trị trong chẩn đoán sớm những trường hợp chưa có tổn thương đại thể quan sát được trên nội soi. ${ }^{5,6}$ 
Thành phần chủ yếu của nước bọt là nước, các chất điện giải, tế bào biểu mô niêm mạc miệng và một số enzyme như amylase có tác dụng tiêu hóa thức ăn ngay từ khoang miệng. Pepsin là một protease có tiền chất là pepsinogen, được tổng hợp từ tế bào chính của dạ dày sau đó bài tiết vào dịch dạ dày do vậy bình thường trong nước bọt không có pepsin. Sự xuất hiện của pepsin trong nước bọt có thể gợi ý tình trạng có dịch dạ dày trào ngược lên vùng miệng. Tuy nhiên các dữ liệu hiện nay chưa đưa ra được khoảng thời gian pepsin tồn tại trong khoang miệng của bệnh nhân. Peptest là kĩ thuật cho phép xác định một cách định tính (có hoặc không) và định lượng nồng độ pepsin có trong mẫu nước bọt. Các nghiên cứu hiện nay về giá trị chẩn đoán GERD của Peptest còn nhiều khác biệt trong việc lựa chọn đối tượng và thời điểm thực hiện kĩ thuật.7-9 Một phân tích gộp về giá trị chẩn đoán GERD của các phương pháp thăm dò cho thấy tỉ lệ GERD chẩn đoán bới phương pháp xác định pepsin trong nước bọt khoảng 0,42-0,47 với tiêu chuẩn xác định dựa trên đo pH-trở kháng thực quản 24 giờ có hoặc không có nội soi. ${ }^{10}$ PepTest là kĩ thuật mới, không xâm lấn, có chi phí hợp lí và được kì vọng là một kĩ thuật có thể áp dụng để chẩn đoán nhanh GERD, đặc biệt trên các đối tượng không thể thực hiện được các phương pháp xâm lấn khác. Hiện nay kĩ thuật PepTest chưa được áp dụng tại Việt Nam, do đó, chúng tôi tiến hành nghiên cứu bước đầu trên cỡ mẫu nhỏ để xác định nồng độ pepsin và khảo sát mối liên quan giữa kết quả định tính, nồng độ pepsin trong nước bọt với đặc điểm trên nội soi và mô bệnh học niêm mạc thực quản của các bệnh nhân có triệu chứng trào ngược dạ dày thực quản.

\section{II. ĐÓI TƯỢNG VÀ PHƯƠNG PHÁP}

\section{1. Đối tượng}

Thiết kế nghiên cứu: Mô tả tiến cứu.
Đối tượng nghiên cứu: Các bệnh nhân đến khám tại phòng khám đa khoa Hoàng Long, có triệu chứng trào ngược dạ dày thực quản và có đầy đủ kết quả Peptest cả định tính và định lượng tại 2 thời điểm, nội soi đường tiêu hoá trên và sinh thiết niêm mạc thực quản tại vị trí trên đường $Z 5 \mathrm{~cm}$. Bệnh nhân được xác định có triệu chứng trào ngược dạ dày thực quản khi có triệu chứng điển hình gồm nóng rát sau xương ức và trào ngược; hoặc các triệu chứng ngoài thực quản nghi ngờ do trào ngược gây ra như viêm họng mạn tính, ho kéo dài, khó thở, cảm giác có khối ở cổ.

\section{Phương pháp}

Thu thập số liệu: Các số liệu thu thập theo bệnh án nghiên cứu được thiết kế sã̃n bao gồm thông tin về nhân khẩu học, kết quả nội soi, kết quả Peptest bao gồm kết quả định tính và định lượng nồng độ pepsin trong nước bọt, kết quả mô bệnh học của niêm mạc thực quản từ mẫu sinh thiết qua nội soi.

Test nhanh phát hiện pepsin trong nước bọt (Peptest): Mẫu $2 \mathrm{ml}$ nước bọt được thu thập tại hai thời điểm (trong vòng 1 tiếng sau ăn tối và ngay sau khi ngủ dậy vào buổi sáng), bảo quản trong ống riêng có chứa sẵn dung dịch bảo quản để trong ngăn mát tủ lạnh (nhiệt độ $4^{\circ} \mathrm{C}$ ). ${ }^{11}$ Mỗi mẫu nước bọt sẽ được tiến hành phát hiện pepsin bằng thiết bị Peptest (RD Biomed Ltd, UK), các mẫu có kết quả định tính dương tính sẽ được tiến hành định lượng nồng độ pepsin. Nồng độ pepsin tối thiểu cho kết quả dương tính là $16 \mathrm{ng} / \mathrm{mL}$.

Đánh giá tổn thương viêm thực quản trào ngược (VTQTN) bằng nội soi đường tiêu hoá trên: mức độ tổn thương được đánh giá từ độ $\mathrm{A}$ đến $\mathrm{D}$ theo phân loại Los Angeles. ${ }^{12}$

Mô bệnh học: Các bệnh nhân được nội soi và sinh thiết 2 mảnh niêm mạc thực quản tại vị trí $5 \mathrm{~cm}$ trên đường $Z$, tiêu bản được nhuộm hematoxyline - eosin. Mức độ viêm thực quản 
do trào ngược được phân loại theo Esohisto dựa trên bốn yếu tố: mức độ tăng sản lớp đáy, độ dài của nhú niêm mạc, độ giãn khoảng gian bào và thâm nhập tế bào viêm (bạch cầu ưa acid, bạch cầu trung tính, bạch cầu đơn nhân) trong biểu mô (Bảng 1). Mỗi yếu tố được đánh giá trên thang điểm từ 0 đến 2 , điểm mức độ viêm thực quản được tính bằng tổng điểm của các yếu tố chia cho tổng số yếu tố đánh giá. Trong đó, điểm 0-0,25 là bình thường, 0,50,75 là viêm thực quản nhẹ, $\geq 1$ là viêm thực quản nặng. ${ }^{13}$

Bảng 1. Tiêu chuẩn chẩn đoán viêm niêm mạc thực quản trên mô bệnh học theo Esohisto ${ }^{13}$

\begin{tabular}{lccc}
\hline \multirow{2}{*}{ Đặc điểm } & \multicolumn{3}{c}{ Điểm } \\
\cline { 2 - 4 } & $\mathbf{0}$ & $\mathbf{1}$ & $\mathbf{2}$ \\
\hline Quá sản lớp tế bào đáy & $<15 \mu \mathrm{m}$ & $15-30 \mu \mathrm{m}$ & $>30 \mu \mathrm{m}$ \\
\hline Dài nhú niêm mạc & $<50 \%$ & $50-75 \%$ & $>75 \%$ \\
\hline Giãn khoảng gian bào & Không giãn & Giãn nhẹ & Giãn rộng \\
\hline Thâm nhập thế bào viêm & Không có & $1-2$ tế bào & $>2$ tế bào \\
Bạch cầu ưa axit & Không có & $1-2$ tế bào & $>2$ tế bào \\
Bạch cầu trung tính & $<10$ tế bào & tế bào & $>30$ tế bào \\
Bạch cầu đơn nhân & & & \\
\hline
\end{tabular}

\section{Xử lý số liệu}

Số liệu được nhập thông qua phần mềm Epidata 3.1 và xử lý bằng phần mềm SPSS 23.0. Các biến định tính được biểu diễn dưới dạng số đếm và tỷ lệ phần trăm. Các biến liên tục được biểu diễn dưới dạng trung bình (độ lệch chuẩn) hoặc trung vị (khoảng tứ phân vị). Sự khác biệt của giá trị định lượng nồng độ pepsin trên mẫu test nhanh Peptest giữa các nhóm được kiểm định bằng $t$-test với hai mẫu độc lập hoặc Mann- Whitney.

\section{3. Đạo đức nghiên cứru}

Nghiên cứu đã được thông qua bởi Hội đồng Đạo đức trong nghiên cứu Y sinh học Viện Nghiên cứu $Y$ học Đinh Tiên Hoàng theo quyết định số IRB-1909 ngày 01 tháng 03 năm 2020.

\section{KÉT QUẢ}

\section{1. Đặc điểm bệnh nhân trong mẫu nghiên cứu}

Từ ngày 24/09/2020 đến ngày 30/12/2020, nhóm nghiên cứu thu tuyển được 30 bệnh nhân thoả mãn tiêu chuẩn lựa chọn. Đặc điểm chung và triệu chứng lâm sàng của các bệnh nhân được thể hiện tại bảng 2. Hầu hết các bệnh nhân đều có tiền sử trào ngược dạ dày thực quản $(96,7 \%)$. Các triệu chứng thường gặp là trào ngược, ợ hơi, nóng rát sau xương ức, đau thượng vị, và đầy bụng (40\%). 5/30 bệnh nhân $(16,7 \%)$ không có biểu hiện các triệu chứng điển hình của GERD (nóng rát sau xương ức và trào ngược). Phần lớn các bệnh nhân có viêm thực quản trào ngược trên nội soi (70\%), trong đó chủ yếu là độ $A$ theo phân loại Los Angeles (63,4\%). 11/30 bệnh nhân được chẩn đoán có hình ảnh viêm niêm mạc thực quản trên mô bệnh học và đều là viêm mức độ nhẹ. 
Bảng 2. Đặc điểm chung bệnh nhân trong mẫu nghiên cứu $(n=30)$

\section{Đặc điểm}

Tuổi, trung vị (IQR), min-max

Giới (nam/nữ)

Có tiền sử trào ngược dạ dày-thực quản, $\mathrm{n}(\%)$

Triệu chứng lâm sàng, $\mathrm{n}$ (\%)

Triệu chứng GERD điển hình

Nóng rát sau xương ức

Trào ngược

Triệu chứng GERD ngoài thực quản

\begin{tabular}{|c|c|}
\hline Viêm/rát họng mạn tính & $6(20,0)$ \\
\hline Ho kéo dài & $3(10,0)$ \\
\hline Đau ngực không do tim & $11(36,7)$ \\
\hline Khó thở & $9(30,0)$ \\
\hline Cảm giác có khối ở cổ & $10(33,3)$ \\
\hline \multicolumn{2}{|l|}{ Triệu chứng GERD không điển hình khác } \\
\hline Đau thượng vị & $12(40,0)$ \\
\hline Đầy bụng & $12(40,0)$ \\
\hline Ợ hơi & $19(63,3)$ \\
\hline Buồn nôn & $4(13,3)$ \\
\hline Nôn & $1(3,3)$ \\
\hline Gầy sút cân & $6(20,0)$ \\
\hline \multicolumn{2}{|l|}{ Điểm lâm sàng } \\
\hline $\begin{array}{l}\text { Điểm GERDQ, trung vị (IQR) } \\
\text { Điểm GERDQ } \geq 8, \mathrm{n}(\%)\end{array}$ & $\begin{array}{c}6,0(5,8-9,0) \\
11(36,7)\end{array}$ \\
\hline Điểm FSSG, trung bình (độ lệch chuẩn) & $10,3(6,6)$ \\
\hline Điểm FSSG $\geq 8, \mathrm{n}(\%)$ & $19(63,3)$ \\
\hline \multicolumn{2}{|l|}{ Đặc điểm nội soi, n(\%) } \\
\hline Không có VTQTN & $9(30,0)$ \\
\hline Có VTQTN & $21(70,0)$ \\
\hline Độ A & $19(63,4)$ \\
\hline Độ B & $1(3,3)$ \\
\hline Độ C & $1(3,3)$ \\
\hline
\end{tabular}

\section{Kết quả}

$38,5(35,0-48,3), 25-65$

$16 / 14$

$29(96,7)$

$12(40,0)$

$21(70,0)$

$6(20,0)$

$9(30,0)$

$10(33,3)$

$12(40,0)$

$12(40,0)$

$1(3,3)$

$6(20,0)$
$11(36,7)$

$10,3(6,6)$

$19(63,3)$

Đặc điểm mô bệnh học, n (\%) 
Quá sản lớp đáy

$<15 \%$

$24(80,0)$

$15-30 \%$

$6(20,0)$

$>30 \%$

$0(0)$

Dài nhú niêm mạc

$<50 \%$

$17(56,7)$

$50-75 \%$

$11(36,7)$

$>75 \%$

$2(6,6)$

$\begin{array}{lc}\text { Có giãn khoảng gian bào } & 4(13,3) \\ \text { Có thâm nhập tế bào viêm } & 10(33,3) \\ \text { Có kết luận niêm mạc thực quản } & 11(36,7)\end{array}$

VTQTN: Viêm thực quản trào ngược

\section{Kết quả Peptest định tính}

Tất cả các bệnh nhân đều có kết quả dương tính ít nhất một trong hai mẫu nước bọt. Trong 29/30 bệnh nhân có đầy đủ kết quả Peptest tại cả 2 thời điểm. 25 bệnh nhân $(83,3 \%)$ có kết quả dương tính ở cả hai mẫu. Bảng 3 so sánh kết quả định tính của Peptest so với kết quả có VTQTN trên nội soi và mô bệnh học. Không có sự khác biệt về tỷ lệ cả hai mẫu nước bọt dương tính ở hai nhóm bệnh nhân có và không có VTQTN trên cả kết quả nội soi và mô bệnh học $(p>0,05)$.

Bảng 3. Kết quả Peptest định tính so với kết quả nội soi và mô bệnh học

\begin{tabular}{lccc}
\hline \multicolumn{1}{c}{ Đặc điểm } & $\mathbf{n}$ & $\begin{array}{c}\text { Kết quả PepTest } \\
\text { Tỷ lệ dương tính } \\
\text { (cả hai mấu) }\end{array}$ & $\mathbf{p ~}$ \\
\hline Kết quả nội soi & & & \multirow{2}{*}{0,593} \\
\hline Có VTQTN & 21 & $17(81,0)$ & \\
\hline Không VTQTN & 9 & $8(88,9)$ & \multirow{2}{*}{0,317} \\
\hline Kết quả mô bệnh học & & $11(91,7)$ & \\
\hline Viêm niêm mạc thực quản & 12 & $14(77,8)$ & \\
\hline Không viêm niêm mạc thực quản & 18 & & \\
\hline
\end{tabular}

VTQTN: Viêm thực quản trào ngược

\section{Kết quả định lượng của Peptest}

Nồng độ pepsin ở mẫu sau ăn tối và trước ăn sáng có trung vị (khoảng tứ phân vị) lần lượt là 124,1 (60 - 174,8), và 104,5 (58,3 - 159,5). Không có sự khác biệt giữa trung vị giá trị định lượng của các bệnh nhân tại hai thời điểm $(p=0,69)$. Khi so sánh sự khác biệt về nồng độ pepsin giữa hai thời điểm trên 25 bệnh nhân có kết quả dương tính cả 2 mẫu, không có sự khác biệt có ý nghĩa thống kê về sự chênh lệch nồng độ pepsin giữa hai thời điểm $(p=0,77)$. Hình 1 mô tả phân bố giá trị nồng độ pepsin của hai mẫu nước bọt tại hai thời điểm. Kết quả cho thấy, phần lớn bệnh nhân (29/30) có nồng độ pepsin > $32 \mathrm{ng} / \mathrm{ml}$ và < 200 ng/ml (27/30 bệnh nhân). 


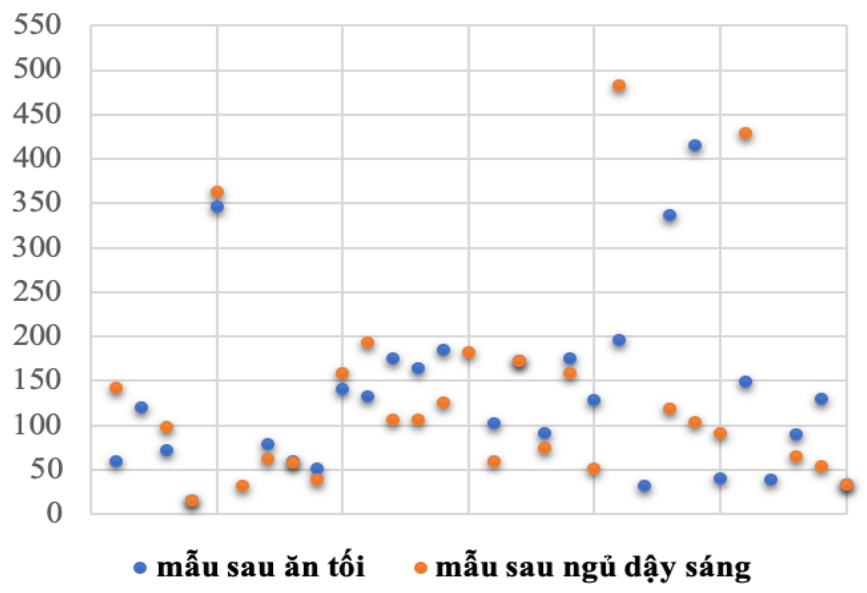

Hình 1. Phân bố nồng độ pepsin ở 2 mẫu nước bọt của 30 bệnh nhân

Bảng 4 trình bày mối liên quan giữa kết quả Peptest định lượng với kết quả nội soi và mô bệnh học. Không có sự khác biệt có ý nghĩa thống kê giữa trung vị nồng độ pepsin giữa nhóm bệnh nhân có và không có VTNTQ trên nội soi và mô bệnh học $(p>0,05)$.

Bảng 4. Mối liên quan giữa nồng độ pepsin với kết quả nội soi và mô bệnh học

\begin{tabular}{|c|c|c|c|c|c|}
\hline Đặc điểm & $\mathbf{n}$ & $\begin{array}{l}\text { Nồng độ pepsin } \\
\text { sau ăn tối }{ }^{\star} \\
\text { (ng/ml) }\end{array}$ & $\mathbf{p}$ & $\begin{array}{c}\text { Nồng độ pepsin } \\
\text { sau khi ngủ dậy sáng* } \\
\text { (ng/ml) }\end{array}$ & $\mathbf{p}$ \\
\hline \multicolumn{6}{|l|}{ Kết quả nội soi } \\
\hline Có VTQTN & 21 & $91,9(39,8-184,8)$ & \multirow{2}{*}{0,60} & $98,4(58,3-125,6)$ & \multirow{2}{*}{0,31} \\
\hline Không VTQTN & 9 & $130,1(105,2-169,7)$ & & $150,8(56,6-188,1)$ & \\
\hline \multicolumn{6}{|l|}{ Kết quả mô bệnh học } \\
\hline Viêm niêm mạc TQ & 12 & $128,0(56,1-185,8)$ & \multirow{2}{*}{0,61} & $115,8(60,9-159,4)$ & \multirow{2}{*}{0,79} \\
\hline Không viêm niêm mạc TQ & 18 & $102,6(60,3-164,9)$ & & $98,4(53,8-172,7)$ & \\
\hline
\end{tabular}

VTQTN: Viêm thực quản trào ngược, TQ: Thực quản, 'Trung vị (khoảng tứ phân vị)

\section{BÀN LUÂN}

Nghiên cứu chúng tôi bước đầu so sánh kết quả định tính và định lượng nồng độ pepsin trong nước bọt của kĩ thuật Peptest với tổn thương viêm thực quản trên hình ảnh nội soi đường tiêu hóa trên và mô bênh học ở các bệnh nhân có triệu chứng trào ngược dạ dày thực quản. Về biểu hiện lâm sàng, triệu chứng điển hình của GERD (trào ngược, nóng rát sau xương ức) chiếm tî lệ cao, các triệu chứng ngoài thực quản có tỉ lệ dao động từ 10 đến gần 40\%. Tỉ lệ nhỏ các bệnh nhân GERD trong nghiên cứu của chúng tôi không có các triệu chứng điển hình của GERD. Tỷ lệ bệnh nhân có điểm GERDQ $\geq 8$ là $36,7 \%, F S S$, $\geq 8$ là $63,3 \%$. 
Peptest là kĩ thuật không xâm lấn nhằm phát hiện pepsin trong nước bọt để chẩn đoán GERD, đặc biệt trong những trường hợp bệnh nhân có triệu chứng ngoài thực quản hoặc khi không thăm dò bằng nội soi hoặc đo $\mathrm{pH}$ trở kháng 24 giờ được (bệnh nhân nhi, phụ nữ có thai, viêm phổi do hít). ${ }^{14,15}$ Một phân tích gộp cho thấy giá trị của kĩ thuật xác định pepsin trong nước bọt có độ đặc hiệu tương đương so với đo pH-trở kháng thực quản 24 giờ có hoặc không kết hợp với nội soi đường tiêu hóa trên, với độ đặc hiệu dao động $62 \%$ - 87\%. ${ }^{10}$

Trong nghiên cứu của chúng tôi ghi nhận tỉ lệ kết quả định tính Peptest dương tính tại ít nhất một mẫu nước bọt, và trên cả hai mẫu nước bọt đều rất cao. Trong đó, tî lệ VTQTN trên nội soi và mô bệnh học có cả hai mẫu nước bọt dương tính ở mức cao lần lượt là 81,0 và $91,7 \%$. Kết quả này cao hơn các nghiên cứu đã báo cáo trước đây. Nghiên cứu của Xing Du và cộng sự trên 3 nhóm đối tượng GERD (xác định bằng đo $\mathrm{pH}$ trở kháng 24 giờ) có tổn thương, không có tổn thương viêm thực quản trên nội soi và nhóm chứng khỏe mạnh, mẫu nước bọt được lấy tại 3 thời điểm (khi đi bộ buổi sáng, sau ăn trưa, và buổi sáng sớm) cho kết quả dương tính trên ít nhất 1 mẫu với tỷ lệ lần lượt là $91 \%$, $53,1 \%$ và 42,9\%. ${ }^{16}$ Một nghiên khác của YanJun Wang báo cáo tỉ lệ dương tính tương ứng Ở các nhóm trên là $76,3 \%$ và $71,9 \%$ và $20,0 \%{ }^{8}$ Nghiên cứu của chúng tôi ghi nhận một tỷ lệ tương đối cao những bệnh nhân không có viêm trên nội soi $(88,9 \%)$ và mô bệnh học $(77,8 \%)$ nhưng có kết quả Peptest dương tính.

Về kết quả định lượng, nồng độ pepsin trong nước bọt ghi nhận tại nghiên cứu này có trung vị tại hai thời điểm là 124,1 và $104,5 \mathrm{ng} / \mathrm{ml}$. Kết quả này còn khác biệt với một số nghiên cứu trước đây của các tác giả Hayat (Anh) và Xing Du (Trung Quốc). ${ }^{16,17}$ Nghiên cứu trên các bệnh nhân chẩn đoán GERD dựa trên đo $\mathrm{pH}$ - trở kháng 24 giờ, thời điểm lấy mẫu nước bọt là khi đi bộ buổi sáng, và trong vòng 1-2 giờ sau ăn trưa, ăn tối, nồng độ pepsin trung bình ở hai nghiên cứu trên lần lượt là 126,0 ng/ml, và 153,3 ng/ml. 16,17 Sự khác biệt này có thể do thời điểm lấy mẫu nước bọt của các nghiên cứu không đồng nhất cũng như tiêu chuẩn lựa chọn bệnh nhân có sự khác biệt. Theo khuyến cáo của nhà sản xuất thiết bị Peptest (RD Biomed Ltd, UK), thời điểm lấy mẫu nước bọt với các bệnh nhân có biểu hiện triệu chứng GERD thường xuyên là trong vòng 1-2 giờ sau bưa ăn tối, và thời điểm buổi sáng sớm trước khi ăn, đối với bệnh nhân có triệu chứng GERD ít thì thời điểm lấy mẫu là trong vòng 15 phút sau khi bệnh nhân xuất hiện triệu chứng nghi ngờ do trào ngược.

Nghiên cứu ghi nhận không có sự khác biệt về nồng độ pepsin ở các nhóm có và không có viêm thực quản trên nội soi. Kết quả này khác so với một số nghiên cứu trước đây cho thấy nồng độ pepsin trong nước bọt ở bệnh nhân GERD có tổn thương viêm thực quản cao hơn có ý nghĩa so với nhóm không có tổn thương trên nội soi và nhóm chứng khỏe mạnh, cao hơn theo mức độ nặng của viêm thực quản trên nội soi. 8,16-18 Sự khác biệt này có thể do cỡ mẫu của chúng tôi còn nhỏ, đồng thời chưa sử dụng kĩ thuật có độ nhạy và độ đặc hiệu cao trong chẩn đoán GERD như đo pH-trở kháng thực quản 24 giờ để đối chiếu. Một số nghiên cứu cho thấy sự hạn chế của các phương pháp thăm dò (như đo pH-trở kháng 24 giờ) trong chẩn đoán tình trạng trào ngược không có viêm thực quản trên nội soi (NERD) trong khi kĩ thuật Peptest có thể cho kết quả chẩn đoán với độ nhạy cao hơn và gợi ý việc sử dụng phối hợp phương pháp này. ${ }^{8,19,20}$ Bởi vậy cần có thêm những đánh giá sâu hơn về mối liên quan giữa nồng độ pepsin nước bọt trên nhóm đối tượng này. 
Nghiên cứu cũng ghi nhận không có sự khác biệt về nồng độ pepsin ở các nhóm có và không có viêm thực quản trên mẫu sinh thiết niêm mạc thực quản. Kết quả của chúng tôi khác với nghiên cứu của Yu-Wen Li và cộng sự (2015) sử dụng tiêu chuẩn giãn khoảng gian bào để chẩn đoán GERD trên mô bệnh học cho thấy nồng độ pepsin trong nước bọt của bệnh nhân GERD có mối tương quan yếu với độ giãn khoảng gian bào. ${ }^{21}$ Điều này có thể do còn chưa có sự thống nhất về các tiêu chuẩn để đánh giá VTQTN trên mô bệnh học. Nghiên cứu của Ismail-Beigi chỉ ra quá sản lớp đáy và dài nhú niêm mạc biểu mô là hai thay đổi mô bệnh học chính ở các bệnh nhân GERD, tuy nhiên độ nhạy và độ đặc hiệu trong chẩn đoán của hai yếu tố trên còn thấp. ${ }^{22}$ Một nghiên cứu khác của Zhou LY và cộng sự sử dụng độ giãn khoảng gian bào (DIS) là tiêu chuẩn trong chẩn đoán GERD ghi nhận độ nhạy và độ đặc hiệu của phương pháp là $62,1 \%$ và $56,1 \% .{ }^{23}$ Nghiên cứu của chúng tôi áp dụng tiêu chuẩn chẩn đoán GERD trên mô bệnh học theo phân loại Esohisto, với sự phối hợp của nhiều yếu tố bao gồm tình trạng quá sản lớp đáy, giãn nhú niêm mạc biểu mô, giãn khoảng gian bào và thâm nhập của tế bào viêm. Đây có thể là một trong những nguyên nhân giải thích tỉ lệ phát hiện viêm niêm mạc thực quản trên mô bệnh học trong nghiên cứu của chúng tôi thấp hơn so với các nghiên cứu trước đây.

Sự khác nhau khi đối chiếu kết quả Peptest định tính, định lượng với tổn thương trên nội soi và mô bệnh học trong chẩn đoán GERD có thể giải thích bởi một số yếu tố. Ở một số người khỏe mạnh vẫn có các cơn trào ngược sinh lý, đặc biệt sau bữa ăn khiến một lượng nhỏ dịch dạ dày có chứa pepsin vào khoang miệng. ${ }^{3}$ Nghiên cứu của Xing Du và cộng sự đã chỉ ra 42,9\% người khỏe mạnh không có triệu chứng có phát hiện pepsin trong nước bọt khi sử dụng giá trị ngưỡng phát hiện là $16 \mathrm{ng} / \mathrm{ml}$, tuy nhiên nồng độ pepsin trong nhóm này thấp hơn nhiều so với nhóm bệnh nhân GERD (trung vị và khoảng phân vị thứ nhất và thứ ba lần lượt là $0,0,25 \mathrm{ng} / \mathrm{ml}$ ). ${ }^{16}$ Bên cạnh đó, các nghiên cứu trước đây cũng đã ghi nhận tỉ lệ bệnh nhân GERD có viêm thực quản trên nội soi chỉ dao động từ $15-50 \%,{ }^{24,25}$ có viêm niêm mạc thực quản trên mô bệnh học khoảng 53-86\%. ${ }^{10}$ Đánh giá tổn thương viêm niêm mạc thực quản đại thể hay vi thể còn phụ thuộc vào nhiều yếu tố như thời gian niêm mạc tiếp xúc với cơn trào ngược, cơ chế thanh thải sinh lý của thực quản đối với cơn trào ngược, vị trí, số mảnh sinh thiết và tiêu chuẩn lựa chọn đánh giá.

Điểm hạn chế trong nghiên cứu của chúng tôi đó là cỡ mẫu còn nhỏ, chưa đối chiếu được với tiêu chuẩn vàng là đo $\mathrm{pH}$-trở kháng thực quản 24 giờ cũng như không thu tuyển được nhóm bệnh nhân viêm thực quản trên nội soi mức độ nặng Los Angeles từ độ $\mathrm{C}$ trở lên để so sánh. Đồng thời cũng chưa có nhóm chứng đa dạng như nhóm chứng người khỏe mạnh không triệu chứng, nhóm bệnh nhân nóng rát chức năng hoặc thực quản tăng nhạy cảm. Một điểm nữa cũng cần lưu ý là giá trị cut-off để xác định mối liên quan giữa nồng độ pepsin và chẩn đoán GERD cũng chưa được xác định trong nghiên cứu này. Tuy nhiên nghiên cứu của chúng tôi cho thấy kĩ thuật Peptest có thể là một xét nghiệm thuận tiện do dễ tiến hành, thời gian có kết quả nhanh và có tiềm năng để chẩn đoán GERD, đặc biệt trong những trường hợp bệnh nhân không có VTNTQ trên nội soi hoặc trên mô bệnh học.

\section{KẾT LUẬN}

Tỉ lệ cao bệnh nhân có triệu chứng trào ngược trong nghiên cứu có kết quả Peptest định tính dương tính. Không có sự khác biệt có ý nghĩa thống kê giữa tỷ lệ dương tính và trung vị nồng độ pepsin giữa nhóm bệnh nhân có và không có viêm trào ngược dạ dày thực quản trên nội soi và mô bệnh học. 


\section{TÀI LIẸU THAM KHẢO}

1. Vakil N, van Zanten SV, Kahrilas P, Dent J, Jones R. The Montreal definition and classification of gastroesophageal reflux disease: a global evidence-based consensus. The American journal of gastroenterology. 2006;101(8):1900-1920; quiz 1943.

2. Min YW, Lim SW, Lee JH, et al. Prevalence of Extraesophageal Symptoms in Patients With Gastroesophageal Reflux Disease: A Multicenter Questionnaire-based Study in Korea. J Neurogastroenterol Motil. 2014;20(1):87-93.

3. Gyawali CP, Kahrilas PJ, Savarino E, et al. Modern diagnosis of GERD: the Lyon Consensus. Gut. 2018;67(7):1351-1362.

4. N E Schindlbeck, A G Klauser, G Berghammer, W Londong, S A MullerLissner. Three year follow up of patients with gastrooesophageal reflux disease. Gut. 1992;33:1016-1019.

5. Dent J. Microscopic esophageal mucosal injury in nonerosive reflux disease. Clinical gastroenterology and hepatology: the official clinical practice journal of the American Gastroenterological Association. 2007;5(1):4-16.

6. Zentilin P, Savarino V, Mastracci L, et al. Reassessment of the diagnostic value of histology in patients with GERD, using multiple biopsy sites and an appropriate control group. The American journal of gastroenterology. 2005;100(10):2299-2306.

7. Race C, Chowdry J, Russell JM, Corfe BM, Riley SA. Studies of salivary pepsin in patients with gastro-oesophageal reflux disease. Alimentary pharmacology \& therapeutics. 2019;49(9):1173-1180.

8. Wang YJ, Lang XQ, Wu D, et al. Salivary Pepsin as an Intrinsic Marker for Diagnosis of
Sub-types of Gastroesophageal Reflux Disease and Gastroesophageal Reflux Diseaserelated Disorders. J Neurogastroenterol Motil. 2020;26(1):74-84.

9. Wang YF, Yang CQ, Chen $Y X$, et al. Validation in China of a non-invasive salivary pepsin biomarker containing two unique human pepsin monoclonal antibodies to diagnose gastroesophageal reflux disease. Journal of digestive diseases. 2019;20(6):278-287.

10. Zhang $M$, Pandolfino JE, Zhou $X$, et al. Assessing different diagnostic tests for gastroesophageal reflux disease: a systematic review and network meta-analysis. Therapeutic advances in gastroenterology. 2019;12:1756284819890537.

11. Ocak E, Kubat G, Yorulmaz I. Immunoserologic pepsin detection in the saliva as a non-invasive rapid diagnostic test for laryngopharyngeal reflux. Balkan Med J. 2015;32(1):46-50.

12. Sami SS, Ragunath K. The Los Angeles Classification of Gastroesophageal Reflux Disease. Video Journal and Encyclopedia of GI Endoscopy. 2013;1(1):103-104.

13. Fiocca $R$, Mastracci $L$, Riddell $R$, et al. Development of consensus guidelines for the histologic recognition of microscopic esophagitis in patients with gastroesophageal reflux disease: the Esohisto project. Hum Pathol. 2010;41(2):223-231.

14. NICE. Peptest for diagnosing gastroesophageal reflux. 2015.

15. Strachan T, Melter J, Barabasová $A$, et al. Pepsin in secretion from the upper respiratory tract as a marker of extraesophageal reflux in children. Cesko-Slovenska Pediatrie. 2017;72:176-181.

16. Du X, Wang F, Hu Z, et al. The diagnostic value of pepsin detection in saliva for 
gastro-esophageal reflux disease: a preliminary study from China. BMC gastroenterology. 2017;17(1):107.

17. Hayat JO, Gabieta-Somnez S, Yazaki $E$, et al. Pepsin in saliva for the diagnosis of gastro-oesophageal reflux disease. Gut. 2015;64(3):373-380.

18. Mohamed H, Khodeer S, Shaheen W. Study of pepsin level in saliva as a noninvasive marker for diagnosis of gastroesophageal reflux disease. 2020;33(1):94-100.

19. Iluyomade A, Olowoyeye A, Fadahunsi $\mathrm{O}$, et al. Interference with daily activities and major adverse events during esophageal $\mathrm{pH}$ monitoring with bravo wireless capsule versus conventional intranasal catheter: a systematic review of randomized controlled trials. Dis Esophagus. 2017;30(3):1-9.

20. Rasijeff AMP, Jackson W, Burke JM, Dettmar P. PWE-172 Does salivary pepsin measurement change diagnostic outcome in patients investigated by $24 \mathrm{~h}$ ph monitoring?
Gut. 2015;64:A287.283-A288.

21. Li YW, Sifrim D, Xie C, Chen M, Xiao YL. Relationship Between Salivary Pepsin Concentration and Esophageal Mucosal Integrity in Patients With Gastroesophageal Reflux Disease. J Neurogastroenterol Motil. 2017;23(4):517-525.

22. Ismail-Beigi F, Horton PF, Pope CE, 2nd. Histological consequences of gastroesophageal reflux in man. Gastroenterology. 1970;58(2):163-174.

23. Zhou LY, Wang Y, Lu JJ, et al. Accuracy of diagnosing gastroesophageal reflux disease by GerdQ, esophageal impedance monitoring and histology. Journal of digestive diseases. 2014;15(5):230-238.

24. Hershcovici T, Fass R. Nonerosive Reflux Disease (NERD) - An Update. J Neurogastroenterol Motil. 2010;16(1):8-21.

25. El-Serag HB. Epidemiology of nonerosive reflux disease. Digestion. 2008;78 Suppl 1:6-10.

\section{Summary}

\section{THE RELATIONSHIP BETWEEN SALIVARY PEPSIN LEVEL AND ESOPHAGITIS ON ENDOSCOPY AND HISTOPATHOLOGY IN PATIENTS WITH GASTROESOPHAGEAL REFLUX SYMPTOMS}

The study was conducted on 30 patients who had gastroesophageal reflux symptoms; quantitative and qualitative pepsin diagnostic tests were conducted from saliva samples (Peptest), upper gastrointestinal endoscopy, and histopathology collected from esophageal mucosal biopsies. The prevalence of patients having positive Peptest results from at least one saliva sample and two samples were $100 \%$ and $83.3 \%$, respectively. The prevalence of patients having esophagitis on endoscopy and histopathology were $70 \%$ and $36.7 \%$, respectively. There was no significant difference in the prevalence of Peptest-positive result between sub-groups with and without esophagitis on both endoscopy and histopathology ( $p>0.05$ ). Pepsin levels in saliva collected after dinner and the morning after were 124.1 and $104.5 \mathrm{ng} / \mathrm{ml}$, and no significant difference was found between subgroups with and without esophagitis on both endoscopy and histopathology $(p>0.05)$.

Keywords: Peptest, endoscopy, histopathology, gastroesophageal reflux disease. 